Int. J. Dev. Biol. 49: 733-744 (2005)

doi: $10.1387 / \mathrm{ijdb} .052015 \mathrm{sj}$

\title{
Plant microRNAs and development
}

\author{
SARA JOVER-GIL, HÉCTOR CANDELA* and MARÍA-ROSA PONCE* \\ División de Genética and Instituto de Bioingeniería, Universidad Miguel Hernández, Campus de Elche, Alicante, Spain
}

\begin{abstract}
MicroRNAs (miRNAs) act as negative regulators of gene expression in eukaryotes, a discovery that has opened an expanding field of biological research. Plant miRNAs are known to repress gene expression posttranscriptionally, mainly by guiding cleavage but also by attenuating the translation of target transcripts. In addition, it has been shown that plant miRNAs can also act at the transcriptional level by directing the methylation of target chromosomal loci. Genetic and biochemical approaches are quickly broadening our knowledge of the biogenesis and function of plant miRNAs. Computational approaches have uncovered an unexpectedly large number of miRNAs and their targets in plants. The targets of plant miRNAs often belong to families of transcription factors involved in the control of developmental processes. We review the status of research in this dynamic field, summarizing recent advances in our understanding of the biogenesis and mechanism of action of plant miRNAs, as well as in the developmental processes they regulate.
\end{abstract}

KEY WORDS: microRNA, Arabidopsis, plant development

\section{History of miRNA research}

Almost twenty years after the isolation of the lin- 4 heterochronic mutant of Caenorhabditis elegans, the corresponding gene was cloned (Lee et al., 1993). Genetic and molecular analyses identified lin-4 as a negative regulator of lin-14 (Ambros, 1989; Arasu et al., 1991). Strikingly, the lin-4 gene lacked an open reading frame and was located in an intron of an apparently unrelated gene. However, it was highly conserved across nematodes and encoded two small untranslated transcripts of 22 and 61 nucleotides (lin- $4 S$ and lin- $4 L$ ). The sequence of the lin- $4 S$ transcript was internal to that of lin- $4 L$ and complementary to seven repeats of the 3' UTR of lin-14. Based on additional genetic and biochemical evidence, a model was proposed to explain the repression exerted by lin-4 on lin-14. According to this model, the lin-4S transcripts were able to block the translation of the lin-14 mRNA by annealing to complementary sequences in its 3' UTR (Lee et al., 1993; Wightman et al., 1993; Olsen and Ambros, 1999). Support for this model came from the ability of the 3' UTR of lin14 to confer the temporal expression pattern of lin-14 to unrelated RNAs (Wightman et al., 1993). lin-4 was considered a rarity until February 2000, when the let-7 gene was also identified in Caenorhabditis elegans (Reinhart et al., 2000). Similar to lin-4, let-7 was found to encode another small RNA that negatively regulated genes involved in the developmental timing of the nematode (Reinhart et al., 2000). The small RNA products of lin4 and let-7 acted as translational repressors by binding to the 3 '
UTRs of their target mRNAs. Conservation across bilaterians was found for let-7, suggesting a more extensive role for miRNAs in gene regulation (Pasquinelli et al., 2000).

Studies on the biosynthesis of flavonols and anthocyanins led to the discovery of co-suppression in plants (Napoli et al., 1990; Van der Krol et al., 1990). This phenomenon was discovered as an unexpected result of experiments aimed at overexpressing the chalcone synthase and dihydroflavonol 4-reductase genes in petunia. Rather than higher expression levels of the genes under study, reduced RNA levels for both the transgene and the endogenous gene were obtained. Among other hypotheses, DNA methylation and the interference of transcription by RNA strands were proposed as possible mechanisms for the observed transacting gene silencing (Napoli et al., 1990; Van der Krol et al., 1990). After the finding, in 1998, that the activity of any given gene could be posttranscriptionally interfered in a highly specific and efficient manner by injecting double-stranded RNAs in Caenorhabditis elegans (Fire et al., 1998; Montgomery et al., 1998), RNA interference (RNAi) became one of the preferred techniques to knock down gene expression in many organisms (reviewed by Hammond et al., 2001).

The link between these apparently unrelated silencing phenomena was apparent after finding that they are mediated by similar short non-coding RNAs, known as microRNAs (miRNAs) and short interfering RNAs (siRNAs), and processed by similar

Abbreviations used in this paper: miRNA, microRNA.

*Address correspondence to: Dr. María Rosa Ponce. División de Genética, Universidad Miguel Hernández, Campus de Elche, Edificio Vinalopó, 03202 Elche, Alicante, Spain. Fax: +34-96-665-8511. e-mail: mrponce@umh.es

\# Present address: Plant Gene Expression Center, University of California, Berkeley, Albany CA 94710, USA. 
enzymes, which are highly conserved from yeast to metazoans and plants (Bernstein et al., 2001; Grishok et al., 2001; Ketting et al., 2001). Distinction of these small RNA species is mainly based on their expression and biogenesis (Ambros et al., 2003a). In this review, we will focus on the most recent advances on the biogenesis and mode of action of plant miRNAs, as well as on their role in plant development.

\section{The biogenesis and export of microRNAs}

miRNAs are small RNAs of approximately 22 nucleotides in length, which derive from non-protein coding transcripts and function as developmentally regulated repressors of gene expression in eukaryotes. Plant and animal miRNAs are diverse in sequence, abundance, expression pattern and genomic location (Lee and Ambros, 2001; Reinhart et al., 2002; Bartel, 2004; Griffiths-Jones, 2004; Griffiths-Jones et al., 2005). Whereas most plant miRNAs derive from their own loci, some reside in introns of other protein-coding genes and in the same orientation, suggesting that they are transcribed in coordination with their host genes (Bartel, 2004; He and Hannon, 2004). Because the annotation of eukaryotic genomes has mainly focused on the thousands of protein-coding genes, miRNA genes are located in regions previously annotated as intergenic, often clustered as polycistronic units (Ambros, 2004; Bartel, 2004).

Studies in plant and animals have shown that miRNA genes are transcribed by RNA polymerase II from their own promoters (Cai et al., 2004; Kurihara and Watanabe, 2004; Lee et al., 2004; Parizotto et al., 2004). As is characteristic of class II genes, the primary transcripts of miRNA genes (also known as pri-miRNAs; Lee et al., 2002) may contain introns and are polyadenylated and 5' capped (Aukerman and Sakai, 2003; Cai et al., 2004; Kurihara and Watanabe, 2004; Lee et al., 2004; Parizotto et al., 2004). These long pri-miRNAs are predicted to adopt imperfect stemloop (hairpin) secondary structures that contain the miRNA in one arm of the stem (Lee et al., 2002; Reinhart et al., 2002). The folding of pri-miRNAs is essential for their processing by class III ribonucleases (RNase III), which cleave them into smaller miRNA precursors (also termed pre-miRNAs; Lee etal., 2003; Zeng et al., 2005). In animals, this task is carried out in the nucleus by the microProcessor protein complex, which includes the RNase III Drosha and the dsRNA-binding protein Pasha/DGCR8 (Denli et al., 2004; Gregory et al., 2004; Han et al., 2004a; Landthaler et al., 2004). In animals, the cleavage of pri-miRNAs into pre-miRNAs and the cleavage of pre-miRNAs into miRNA-miRNA* duplexes are mediated by the RNase III activities of Drosha in the nucleus (Lee et al., 2003) and Dicer in the cytoplasm (Billy et al., 2001; Provost et al., 2002), respectively, making the nucleocytoplasmic export of the pre-miRNAs an essential step in miRNA biogenesis (Lee et al., 2002; Lund et al., 2004). The miRNA and miRNA* strands of the miRNA-miRNA* duplexes originate from complementary arms of the stem, which remain together after cleavage, leaving 2-nucleotide 3' overhangs with 5' monophosphate and 3' hydroxyl ends, as is characteristic of Dicer activity (Elbashir et al., 2001).

Our current knowledge on the biogenesis of plant miRNAs comes from the characterization of Arabidopsis thaliana mutants showing defective miRNA biogenesis. In this species, the DICERLIKE1 ( $D C L 1)$ gene was initially identified based on the develop- mental defects shown by loss-of-function mutants isolated in a variety of screens. These included embryo defects caused by the suspensor1 alleles of DCL 1 (sus 1; Errampalli et al., 1991; Castle et al., 1993; Schwartz et al., 1994; Franzmann et al., 1995; McElver et al., 2001), aberrant female reproductive development, extra vegetative leaves and inflorescence axes and late flowering caused by the short integuments 1 alleles ( $\sin 1$; Robinson-Beers et al., 1992; Lang etal., 1994; Ray et al., 1996) and aberrant floral patterning, fewer axillary meristems and abnormal proliferation of shoot meristem cells caused by the carpel factory allele (caf; Jacobsen et al., 1999; Figure 1C). The involvement of DCL 1 in miRNA biogenesis was proposed after reduced miRNA accumulation was observed in the caf mutant (Park et al., 2002; Reinhart et al., 2002). Loss-of-function mutations of two additional Arabidopsis genes, HYPONASTIC LEAVES1 (HYL1) and HUA ENHANCER1 (HEN1), condition pleiotropic phenotypes similar to those of $d c / 1$ alleles, including small lateral organs, hyponastic (curled up) vegetative leaves with a gradual lamina-to-petiole transition and abaxial trichomes, dense inflorescences, hookshaped cauline leaves, short stature, delayed flowering and low fertility (Figure 1D, E; Lu and Fedoroff, 2000; Chen et al., 2002; Han et al., 2004b; Vazquez et al., 2004; Jover-Gil et al., submitted). Similar to $d c / 1$, hyl1 and hen1 mutations impair the production of miRNAs and lead to a reduced accumulation of miRNAs, suggesting that these genes are also required for miRNA biogenesis (Park et al., 2002; Boutet et al., 2003; Han et al., 2004b; Vazquez et al., 2004).

In Arabidopsis thaliana, the cleavage of pri-miR163 into premiR163 is carried out in two steps by the RNase III activity of DCL1, as inferred from the accumulation of pri-miR163 and the absence of cleavage products resulting from a mutation that damages the RNA helicase domain of DCL1 (Kurihara and Watanabe, 2004). It has recently been hypothesized that plants have an analogous complex to the microProcessor of Drosophila, which would include DCL1 and the dsRNA-binding protein (HYL1), since HYL1 forms part of a complex whose molecular weight coincides with those of HYL1 and DCL1 together (Han et al., 2004b; Tomari and Zamore, 2005). Unlike animals, the cleavage of plant pre-miRNAs into shorter miRNA-miRNA* duplexes is also carried out by DCL1, making it conceivable that all the steps happen in the nucleus (Papp et al., 2003; Kurihara and Watanabe, 2004; Park etal., 2005). In agreement with the nuclear localization of plant miRNA biogenesis, DCL1, HYL1 and HEN1 contain nuclear localization signals (Jacobsen etal., 1999; Lu and Fedoroff, 2000; Chen et al., 2002) and mature miRNAs have been found in the nucleus and, more abundantly, in the cytoplasm, where they may function (Park et al., 2005). In mammalian cells, the export of pre-miRNAs from the nucleus to the cytoplasm is accomplished by Exportin-5 in cooperation with Ran-GTP (Yi et al., 2003; Bohnsack etal., 2004; Lund etal., 2004). HASTY (HST; Telfer and Poethig, 1998), the plant ortholog of Exportin-5, interacts with AtRAN1 (Bollman et al., 2003) and Park and colleagues (2005) have shown that a missense hst-3 mutation, known to preclude the interaction with Ran-GTP, impairs the accumulation of miRNAs, pointing to the involvement of HST in miRNA transport or biogenesis. Consistent with this role, they also found that the transcript levels of several miRNA targets were higher in a putatively null hst mutant (Park et al., 2005). Mutations in this gene also cause developmental defects, such as the curling-up of the leaves, early 
flowering and an accelerated vegetative phase change (Figure 1F; Telfer and Poethig, 1998).

Insight into the role of HEN1 in miRNA biogenesis has been gained recently with the finding that HEN1 is a methyltransferase that methylates miRNA-miRNA* duplexes, but not single stranded miRNAs, miRNA*s, siRNA duplexes, or DNA duplexes (Yu et al., 2005). Whereas the biological significance of this methylation is still unclear, Yu and colleagues have proposed two hypotheses to account for the observed decrease in the amount of miRNAs in hen 1 mutants. According to one of them, the methyl group may act as a protective cap to prevent the degradation of miRNAs by exonucleases. Alternatively, the methyl group might serve as a recognition signal to direct the miRNAs to subsequent steps of the miRNA pathway, which may also increase the stability of miRNAs (Yu et al., 2005).

\section{Posttranscriptional regulation by miRNAs}

Plant miRNAs negatively regulate endogenous target genes whose transcripts are recognized and cleaved based on their extensive or complete complementarity (Rhoades et al., 2002; Bartel and Bartel, 2003). As expected, mutations that impair the biogenesis of miRNAs, such as hy/1, hen1 and hst, lead to the upregulation of genes that are targeted by miRNAs (Boutet et al., 2003; Han et al., 2004b; Vazquez et al., 2004; Park et al., 2005). In plants, each target mRNA usually contains a single miRNA complementary site located in the coding region (Rhoades et al., 2002; Llave et al., 2002a; Bartel, 2004). In contrast, animal miRNAs are often partially complementary to multiple binding sites in the 3' UTR of the target mRNAs (Lee et al., 1993; Wightman et al., 1993; Olsen and Ambros, 1999; Seggerson et al., 2002; Bartel, 2004). Different from most plant miRNAs and similar to animals, miRNA172 is the only plant miRNA known to act by repressing the translation of its targets (Aukerman and Sakai, 2003; Chen, 2004).

In a variety of eukaryotes, the endonuclease activity of the RNA-Induced Silencing Complex (RISC) cleaves target RNA molecules guided by complementary miRNAs or siRNAs (Hammond et al., 2000; Elbashir et al., 2001; Zamore, 2002). The RISC complex characteristically contains a member of the ARGONAUTE (AGO) or PPD protein family, which provides the endonuclease (sometimes referred to as 'slicer') activity of the complex (Liu et al., 2004; Meister et al., 2004; Rand et al., 2004). AGO proteins contain highly conserved PAZ and PIWI domains (Cerutti et al., 2000; Carmell et al., 2002). The PAZ domain binds

Fig. 1. Perturbation of the miRNA pathway causes aberrant rosette and leaf morphology. (A,B) Rosettes of the wild-type Landsberg erecta (Ler; A) and Enkheim-2 (En-2; B) accessions. (C-G) Rosette phenotypes caused by loss-of function mutations in the DCL1 (C), HEN1 (D), HYL1 (E), HST (F) and AGO1 (G) genes, all of which encode proteins of the miRNA machinery. (H) Morphological effects of a semidominant, point mutation that damages the miR166 binding site of ICU4 lalso known as CNA and ATHB-15 ). The ago1, dcl1, hen1 and hyl1 mutations are in a Ler genetic background, whereas hst andicu4 are in a En-2 genetic background. (I-N) Synergistic phenotypes of some double mutants involving ago1, dcl1, hen1, hyl1, hst andicu4. Pictures were taken in our laboratory from plants grown at $20^{\circ} \mathrm{C}$ on agar plates under continuous light, $21(A, B, D-J, L, N)$, $25(\mathrm{M}), 26(\mathrm{C})$ and $37(\mathrm{~K})$ days after sowing. Scale bars indicate $0.2 \mathrm{~mm}(\mathrm{~L})$ and $1 \mathrm{~mm}(A-K, M, N)$
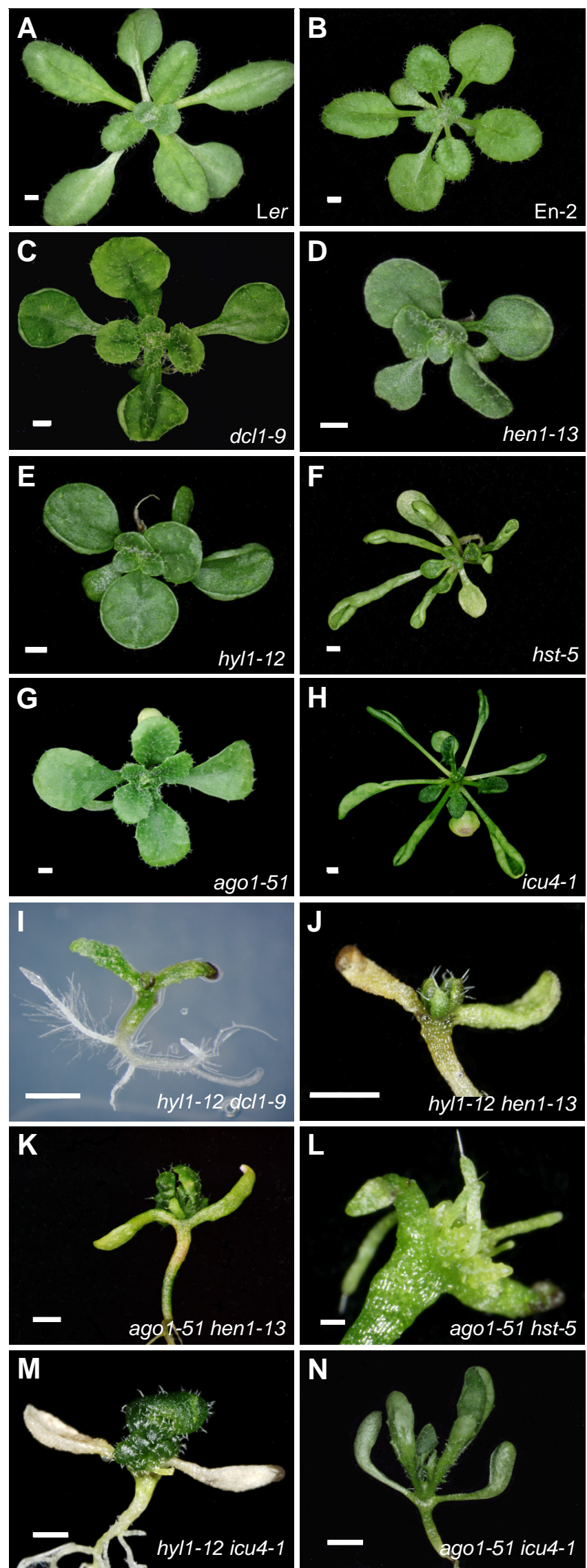
single-stranded RNAs and, with lower affinity, dsRNAs with 3' overhangs (Lingel et al., 2003; Yan et al., 2003). The PIWI domain mediates the interaction with Dicer proteins and provides endonuclease activity (Liu et al., 2004; Parker et al., 2004; Song et al., 2004; Tahbaz et al., 2004). The cleavage of targets occurs at the 10th or 11th nucleotide from the 5' end of the miRNA, regardless of the miRNA length, and requires the base pairing of the 5' end of the miRNA with the mRNA (Palatnik et al., 2003; Xie et al., 2003; Floyd and Bowman, 2004; Jones-Rhoades and Bartel, 2004; Mallory et al., 2004a). The resulting cleavage products have 3' hydroxyl and 5' phosphate groups, similar to the products of other enzymes with 'slicer' activity, such as RNase H (Martinez and Tuschl, 2004; Schwarz et al., 2004; Song et al., 2004).

ARGONAUTE1 (AG01; Bohmert et al., 1998) encodes one of the ten AGO proteins present in the genome of Arabidopsis thaliana (Morel et al., 2002). Several facts suggest that AGO1 forms part of the plant RISC in the miRNA pathway. First, miRNA target genes are upregulated in loss-of-function ago1 mutants, even though miRNA levels are not reduced suggesting that $A G O 1$ acts downstream DCL 1, HYL1 and HEN1 (Kidner and Martienssen, 2004; Vaucheret et al., 2004). Second, several amino acid residues that are conserved in AGO1 have been shown to be essential for the endonuclease activity of other AGO proteins (Liu et al., 2004; Song et al., 2004). Third, the misregulation of endogenous genes due to a faulty miRNA pathway is expected to cause developmental phenotypes, such as those of ago1 mutants (Figure 1G). Null ago1 mutants are sterile and show loss of lateral organ polarity and defective axillary meristem development (Bohmert et al., 1998). In addition, posttranscriptional gene silencing was found to be altered in ago1 mutants, which suggested that their developmental phenotypes derive from altered gene regulation (Fagard etal., 2000). The pleiotropic phenotype conditioned by weaker, hypomorphic ago1 alleles includes the adaxialization of lateral organs, the presence of abaxial trichomes on juvenile leaves, a loss of lamina-petiole distinction, reduced flower size, late flowering, abnormal inflorescence morphology and small stature (Figure 1G; Morel et al., 2002; Kidner and Martienssen, 2004; Jover-Gil et al., submitted). Some of these phenotypes resemble those of hypomorphic $d c / 1$ and null hen 1 and hy/1 mutants (Figure 1C-E, G; Hunter and Poethig, 2003; Vaucheret et al., 2004; Vazquez etal., 2004; Jover-Gil etal., submitted) and are enhanced in double mutants involving mutations affecting the miRNA pathway (Figure 1I-L; Jover-Gil et al., submitted), as is expected if AGO1 is a component of the miRNA pathway.

An interesting discovery was that $D C L 1$ and $A G O 1$ are regulated by miRNAs (Table 1; Xie et al., 2003; Vaucheret et al., 2004; Vazquez et al., 2004), which indicates that the miRNA pathway is subjected to a negative feedback by miRNAs. As expected for a target of miRNA cleavage, AGO1 was upregulated in $d c / 1$ and hen 1 mutants (Vaucheret et al., 2004; Vazquez et al., 2004). In addition, plants carrying a miR168-resistant version of AGO1 (miR168 targets $A G O 1$ ) also showed an upregulation of $A G 01$, which correlated with the severity of the developmental defects displayed (Vaucheret et al., 2004). These phenotypes were similar to those displayed by hy/1, dc/1 and hen 1 mutants. The upregulation of AGO1 was also observed in the null ago1-3 mutant, consistent with AGO1 being both a component of the plant RISC and a target of miRNA regulation (Vaucheret et al., 2004).

After the target mRNAs are cleaved by the RISC, the resulting 3 ' and the 5' cleavage products follow different fates. In Arabidopsis thaliana, the 3' fragments are degraded through the activity of the cytoplasmic 5'-to-3' EXORIBONUCLEASE4 (XRN4), as inferred from the increased stability of these fragments in loss-of-function xrn4 mutants (Souret et al., 2004). The ortholog of XRN4 in Drosophila, $X R N 1$, is involved in the degradation of the 3' fragments after the cleavage by AGO2 in the RISC, and the degradation of the 5' fragment is accomplished by the cytoplasmic exosome, a 3'-to-5' riboexonuclease complex (Orban and Izaurralde, 2005).

TABLE 1

\section{miRNAs KNOWN TO PLAY A ROLE IN DEVELOPMENT}

\begin{tabular}{|c|c|c|c|c|c|}
\hline Organism & microRNA & Approach & Target genes & Function of the target genes & References \\
\hline C. elegans & lin-4 & M & lin-14, lin-28 & Larval development & $1-5$ \\
\hline C. elegans & let-7 & M & lin-41, lin-57 (hbl-1), daf-12, pha-4 & Larval and adult development, dauer formation and aging & $6-10$ \\
\hline C. elegans & Isy-6 & M & $\operatorname{cog}-1$ & Neuron bilateral asymmetric gene expression & 11 \\
\hline C. elegans & mir-273 & $\mathrm{P}$ & die-1 & Neuron bilateral asymmetric gene expression; regulation of $/ s y-6$ & 12 \\
\hline D. melanogaster & bantam & M & hid & Cell proliferation and apoptosis & 13 \\
\hline D. melanogaster & $\mathrm{miR}-14$ & M & Unknown & Apoptosis and fat metabolism & 14 \\
\hline M. musculus & $\mathrm{miR}-181$ & CS & Unknown & Hematopoietic lineage differentiation & 15 \\
\hline M. musculus & miR-375 & CS & Mtpn & Insulin secretion & 16 \\
\hline A. thaliana & $\operatorname{miR} 156$ & $C D$ & SPL2, SPL10 & Floral meristem identity and flowering time & $17-20$ \\
\hline A. thaliana & $\operatorname{miR} 159$ & $\mathrm{CD}$ & MYB33, MYB65 & Plant growth, anther development and flowering time & $17,18,20-24$ \\
\hline A. thaliana & miR-JAW & M & TCP2, TCP3, TCP4, TCP10, TCP24 & Cell division, leaf development and embryo patterning & 22 \\
\hline A. thaliana & miR162 & $\mathrm{CD}$ & $D C L 1$ & $\begin{array}{l}\text { Biogenesis of miRNAs and control of meristem function } \\
\text { in flower development }\end{array}$ & 17,25 \\
\hline A. thaliana & $\begin{array}{l}\text { miR164, including } \\
\text { eep1 (miR164c) }\end{array}$ & $\mathrm{CD}, \mathrm{P}, \mathrm{S}$ & $\begin{array}{l}\text { CUC1, CUC2, NAC1, At5g07680, } \\
\text { At5g61430 }\end{array}$ & $\begin{array}{l}\text { Control of boundary size in meristems and formation and separation } \\
\text { of embryonic, vegetative and floral organs, control of petal number }\end{array}$ & $17-20,26,27$ \\
\hline A. thaliana & $\begin{array}{l}\text { miR165 and miR166, } \\
\text { including men1 (miR166a) }\end{array}$ & $\mathrm{CD}, \mathrm{M}$ & $\begin{array}{l}\text { PHB, PHV, REV, ATHB8, } \\
\text { ICU4 }(A T H B-15, C N A)\end{array}$ & $\begin{array}{l}\text { Embryo patterning, postembryonic meristem initiation, axial meristem } \\
\text { initiation, vascular development, leaf polarity and meristem size regulation }\end{array}$ & $17,18,28-31$ \\
\hline A. thaliana & miR168 & $\mathrm{CD}, \mathrm{P}$ & AGO1 & miRNA pathway and stem cell function and organ formation & $17,18,20,32$ \\
\hline A. thaliana & $\operatorname{miR} 171$ & $\mathrm{CD}, \mathrm{P}$ & $S C L 6, S C L 6-I /, S C L 6-I / I$ & Radial patterning in roots & $17,18,20,33$ \\
\hline A. thaliana & $\begin{array}{l}\text { miR172, including eat } \\
\text { (miR172a-2) }\end{array}$ & $\mathrm{CD}, \mathrm{M}$ & AP2, TOE1, TOE2, TOE3 & Specification of flower organ identity and flowering time & $19,21,34,35$ \\
\hline
\end{tabular}

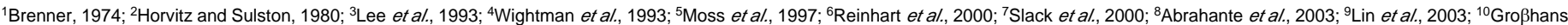

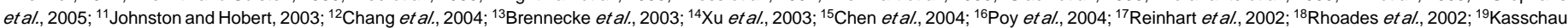

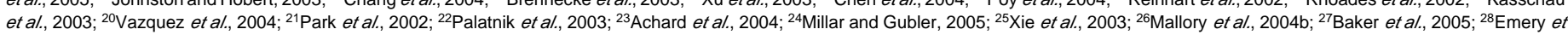

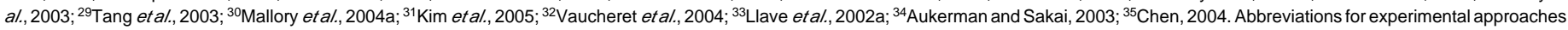
are as follows: M: mutant screen; P: computational prediction; CS: cloning of small RNAs; CD: cloning of Dicer cleavage products; S: spontaneous mutation. 
In plants, a higher instability has been reported for the 5' cleavage products (Llave et al., 2002a) although the degradation mechanism is still unclear. Shen and Goodman (2004) managed to clone the 5' cleavage products of several miRNA targets from Arabidopsis thaliana and from mouse, which led them to the discovery that an oligouridine tail is selectively added to their 3' ends. This postcleavage uridylation might be responsible for the observed enhancement in the decay of the 5' fragments (Shen and Goodman, 2004).

\section{Transcriptional regulation by miRNAs}

Using methylation-sensitive restriction enzymes and bisulfite sequencing, Bao et al. (2004) found that the PHABULOSA (PHB) and PHAVOLUTA ( $P H V$ genes of Arabidopsis thaliana, two wellcharacterized targets of miR166, are methylated in most wild-type cells. However, $P H B$ and $P H V$ are not methylated in cells carrying phb and phv semidominant mutations that damage the miR166 binding site. To investigate the relationship between gene methylation and miRNAs, the authors generated phb/PHB and phv/PHV heterozygous plants by combining wild-type and mutant alleles from different ecotypes, which are distinguishable on the basis of sequence polymorphisms. Remarkably, the wild-type alleles were differentially methylated in these heterozygotes, pointing to a novel mode of action, in which miRNAs must interact with their binding sites to drive the methylation of chromosomal loci in cis. Because the miRNA binding sites of $P H V$ and $P H B$ span two exons (Figure 2A), miRNA166 can only interact with spliced $P H V$ and $P H B$ transcripts, suggesting that the epigenetic modification of these genes happens or is induced before the nascent transcripts are released from the template chromosome (Bao et al., 2004).

This apparently direct interaction between the miRNA and the template chromosome is reminiscent of the silencing of chromatin mediated by the RITS (RNA-induced initiator of transcriptional gene silencing) complex, as noticed by Bao and colleagues (2004). In Schizosaccharomyces pombe, the RITS complex contains, among other partners, the AGO protein Ago1 and requires siRNAs produced by Dicer to associate with target loci (Verdel et al., 2004). Recent evidence indicates that the RITS acts in cis to allow the maintenance of transcriptional and posttranscriptional silencing and that it might be involved in the processing of nascent transcripts into siRNAs (Noma et al., 2004). Given these mechanistic similarities, it will be interesting to investigate if the methylation and silencing of $P H B$ and $P H V$ guided by miRNAs depend on protein complexes similar or equivalent to the RITS complex.

\section{Discovering miRNA genes and their targets}

Forward genetic approaches based on the isolation of mutants have not been very successful for identifying miRNA genes in plants and animals (Table 1). So far, the only loss-of-function allele of a plant miRNA gene identified is a transposon insertion in the EARL Y EXTRA PETALS1 gene (EEP1, also known as MIR164C ), recently reported by the Meyerowitz lab (Baker et al., 2005). The failure to identify more loss-of-function alleles of miRNA genes might be explained by the difficulty in disrupting their function, since miRNAs are not suitable targets for mutagens because they are small and because they are not affected by frameshift, missense or nonsense mutations (Eddy, 1999). Functional redundancy might be another cause, since plant genomes usually contain several genes for each miRNA (Llave et al., 2002b; Park et al., 2002; Reinhart et al., 2002; Jones-Rhoades and Bartel, 2004; Sunkar and Zhu, 2004; Wang et al., 2004a; 2004b). In accordance with this, activation tagging approaches have been more efficient in Arabidopsis thaliana and have rendered gain-of-function alleles of $J A W$ (Palatnik et al., 2003), which was the first plant miRNA gene identified in a mutant screen and, recently, of EARL Y ACTIVATION TAGGED (EAT, also known as MIR172a-2; Aukerman and Sakai, 2003) and MERISTEM ENLARGEMENT1 (MEN1, also known as MIR166a; Kim et al., 2005).

The preferential cloning of small RNAs has yielded libraries that include housekeeping RNAs, miRNAs, siRNAs and other small RNAs of unknown function in plants and animals (Elbashir et al., 2001; Lagos-Quintana et al., 2001; Lau et al., 2001; Lee and Ambros, 2001; Llave etal., 2002b; Park etal., 2002; Reinhart etal., 2002; Ambros et al., 2003b; Aravin et al., 2003; Wang et al., 2004b). New cloning methods that exploit the small size and the biochemical properties (i.e. the 5' phosphate and the 3' hydroxyl groups) of Dicer-dependent cleavage products, first used in animal systems, have been instrumental in the identification of miRNAs (Elbashir et al., 2001; Lau et al., 2001). In Arabidopsis thaliana, the selective cloning of short RNAs after ligation of adaptors to the 5' phosphate and the 3' hydroxyl groups has been an effective way of identifying new miRNAs (Llave et al., 2002b; Park et al., 2002; Reinhart et al., 2002).

Some authors, however, have pointed to the limited scope of direct cloning, highlighting the advantages of bioinformatic predictions as a complementary strategy for identifying low-abundance miRNAs (Lai et al., 2003; Bonnet et al., 2004; Jones-Rhoades and Bartel, 2004; Wang et al., 2004a; Adai et al., 2005). The computational prediction of miRNAs is based on the properties of already-

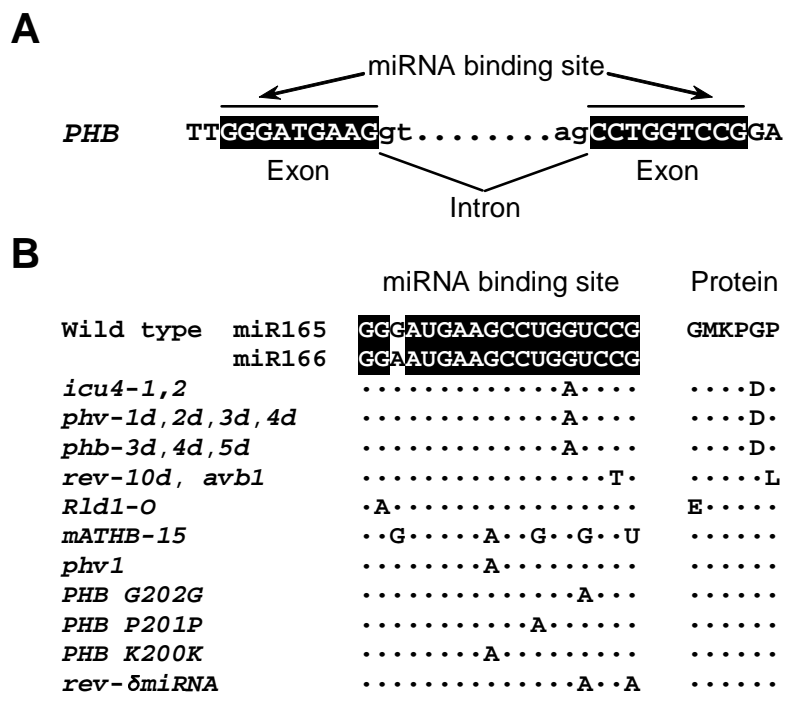

Fig. 2. Nucleotide changes within the miR165/166 binding site of HDZip III genes. (A) The miRNA binding site of the PHB gene. (B) Alleles and transgenes of HD-Zip III gene family members from Arabidopsis thaliana, Zea mays ( Rld1-O ) and Nicotiana sylvestris (phv1) with mutations affecting the miR165/166 binding site. The sequences have been taken from Ochando et al. (submitted), McConnell et al. (2001), Emery et al. (2003), Zhong and Ye (2004), Juarezet al. (2004), Kim et al. (2005), McHale and Koning (2004) and Mallory et al. (2004a). 
known pre-miRNAs, including their preferential location within nonprotein coding or intronic regions, their high conservation across related species, their ability to form stem-loop secondary structures and their characteristic pattern of nucleotide divergence (Lai et al., 2003). The extraordinary sequence conservation of the stem-loops in related animal species, often higher than that of protein-coding genes, has been useful for miRNA prediction (Ambros et al., 2003b; Lai et al., 2003; Lim et al., 2003a; 2003b). In plants, the variable length and higher complexity of the stem-loops makes the prediction of miRNAs more difficult than in animals (Llave et al., 2002b; Reinhart et al., 2002). To identify new miRNAs, most algorithms take advantage of the availability of the full genome sequences of rice and Arabidopsis (Bonnet et al., 2004; JonesRhoades and Bartel, 2004; Wang et al., 2004a; 2004b; Adai et al., 2005). Often, the search for new miRNAs focuses on the pool of intergenic and intronic sequences of Arabidopsis thaliana, where most miRNAs are expected to be located (Bonnet et al., 2004; Wang et al., 2004a; Adai et al., 2005). All approaches rely on the identification of sequences that meet the structural requirements of miRNAs and miRNA precursors, including properties such as the ability to form a stem-loop, the lengths of the predicted miRNA and the loop, the number of mismatches, or the $\mathrm{G}+\mathrm{C}$ content (Bonnet et al., 2004; Jones-Rhoades and Bartel, 2004; Wang et al., 2004a; 2004b; Adai et al., 2005). Some algorithms, which use the evolutionary conservation of miRNAs as a criterion for their predictions, also include rice sequences in their analyses (Bonnet et al., 2004; Jones-Rhoades and Bartel, 2004; Wang et al., 2004a;2004b; Adai etal., 2005). In some cases, these algorithms boost their predictive power by simultaneously searching for target mRNAs in the same genome (Adai et al., 2005) or by searching for conserved mRNA:miRNA interactions in the genomes of Arabidopsis and rice (Jones-Rhoades and Bartel, 2004). The computational prediction of targets has been facilitated in plants by their near-perfect complementarity with the miRNAs (Rhoades et al., 2002; Bonnet et al., 2004; Jones-Rhoades and Bartel, 2004). Searches for mRNAs with three or fewer mismatches relative to the miRNA sequence have had a limited success in predicting targets in Arabidopsis thaliana (Rhoades et al., 2002). By searching for conserved mRNA:miRNA interactions between Arabidopsis and rice, the method of Jones-Rhoades and Bartel was the most sensitive and allowed them to predict targets even when additional mismatches and gaps were present in the mRNA:miRNA duplexes (Jones-Rhoades and Bartel, 2004).

The miRNA Registry, a database aimed at standardizing the nomenclature of newly described miRNAs and at compiling the available information on published miRNAs, currently stores information on 112 Arabidopsis, 134 rice and 40 maize miRNAs genes (http://www.sanger.ac.uk/cgi-bin/Rfam/mirna/browse.pl; GriffithsJones, 2004).

\section{Experimental validation of predicted miRNAs and their targets in plants}

Several protocols based on the fact that most plant targets are downregulated by miRNA-directed cleavage are available for the validation of predicted miRNA targets. The Carrington lab pioneered this field by applying two experimental approaches to the study of the cleavage of suspected targets (Llave et al., 2002a). The first approach uses a modified RNA ligase-mediated Rapid
Amplification of cDNA Ends (5' RACE) protocol to map the cleavage site within the target mRNA taking advantage of the characteristically uncapped 5' phosphate groups of RNase III 3' products (Llave et al., 2002b). This technique allowed them to validate, for the first time in plants, three SCARECROW-LIKE (SCL) genes as targets of miR39 (Llave et al., 2002a).

The second approach involves the coexpression of constructs carrying a miRNA and its putative target in Nicotiana benthamiana leaves co-infiltrated with Agrobacterium (Llave et al., 2002a). This technique has been applied to demonstrate the miR159directed cleavage of MYB33 (Achard etal., 2004) and the miR39directed cleavage of SCL6 (Llave et al., 2002a). By introducing point mutations that disrupt the complementarity of the miRNA with the target transcript, this method has also allowed researchers to study the importance of base pairing for cleavage (Llave et al., 2002a).

To assess the role of cleavage in the repression of miRNA targets, several authors have engineered cleavage-resistant versions of the corresponding genes by introducing silent mutations that disrupt the complementarity of the miRNA and the mRNA. Plants expressing cleavage-resistant transgenes of CUP-SHAPED COTYLEDON1 (CUC1), CUC2, MYB33, TCP2, TCP4 and PHB displayed a range of mutant phenotypes that indicate the importance of miRNA regulation for plant development (Palatnik et al., 2003; Laufs et al., 2004; Mallory et al., 2004a; 2004b; Millar and Gubler, 2005). In addition to these methods, evidence for the expression of computationally predicted miRNA genes comes from a variety of sources, including Northern blots, 5' RACE, ESTs and the identification of the predicted miRNA in the Arabidopsis Small RNA Project database or in libraries of small RNAs (Wang et al., 2004a; Jones-Rhoades and Bartel, 2004; Gustafson et al., 2005).

\section{The evolution of miRNA genes}

Little is known about the evolution of plant miRNAs. Many miRNA genes are conserved in rice and Arabidopsis thaliana, indicating that their origin predates the divergence of monocot and dicot plants approximately 150 million years ago (Pasquinelli et al., 2000; Floyd and Bowman, 2004). The conservation of the miRNA binding sites of class III homeodomain-leucine zipper (HD-ZIP III) genes from bryophytes to seed plants indicates that the posttranscriptional regulation mediated by miR166 is a mechanism that can be traced back more than 400 million years (Floyd and Bowman, 2004). In contrast, a recent study has shown that some miRNA genes of Arabidopsis thaliana have originated recently and are not conserved in monocots and dicots (Allen et al., 2004). These miRNAs seem to derive from inverted duplications and, because of their recent origin, do not belong to miRNA gene families (Allen et al., 2004). According to the model of Allen and colleagues, the transcription of inverted duplications of target genes results in the formation of hairpins that are eventually processed into miRNAs by the miRNA machinery, leading to the targeting of the transcripts of the original gene (Allen et al., 2004). Two miRNA genes of Arabidopsis thaliana not conserved in monocots are MIR161 and MIR163, in which the similarity between the miRNA genes and their targets extends outside the miRNA, in both the miRNA and the miRNA* arms, as might be expected if their origin is recent (Allen et al., 2004). In the same 
way as miRNAs, MIR161 and MIR163 require DCL1 and HEN1 for their biogenesis and are able to direct the cleavage of their targets (Allen et al., 2004).

\section{The control of plant development by miRNAs: some examples}

The targets of plant miRNAs often encode members of large families of transcription factors important for development, a finding consistent with the pleiotropic developmental defects caused by mutations in genes that encode elements of the miRNA pathway (Figure 1C-G; Table 1; Rhoades et al., 2002; Dugas and Bartel, 2004; Mallory et al., 2004a; 2004b). In addition, mutations in some target genes and in the miRNA genes that regulate them also cause developmental defects (Figure $1 \mathrm{H}$ ). Below, we briefly summarize current knowledge on the function of some plant miRNAs, their targets and the developmental processes in which they are involved (Table 1).

\section{miR-JAW}

With the isolation of four independent activation-tagged alleles, MIR-JAW became the first miRNA gene to be identified in a mutant screen (Palatnik et al., 2003). The pleiotropic phenotype of dominant jaw-D mutants resembled that of cincinnata ( $\operatorname{cin})$ mutants of Antirrhinum majus in the aberrant curling of the leaves, whose surface had a non-zero Gaussian curvature (Nath et al., 2003; Palatnik et al., 2003). CIN encodes a member of the TCP family of transcription factors (Nath et al., 2003), named after its first characterized members: teosinte branched1 (tb1) of maize, cycloidea (cyc) of Antirrhinum majus and PCF1 and PCF2 of rice (Cubas et al., 1999). Members of this family are thought to regulate cell division and growth (Cubas et al., 1999). This and the similarity of the cin loss-of-function and jaw- $D$ gain-of-function phenotypes made TCP genes good candidates to be targets of miR-JAW. MIR$J A W$ was found to be expressed in wild-type shoot apices, inflorescences and siliques (Palatnik et al., 2003).

The overexpression of MIR-JAW in jaw-D mutants caused cotyledon epinasty, fruit abnormalities, serration of leaf margins and delay in flowering (Palatnik et al., 2003). Five TCP genes, closely related to $C / N$, were found to be downregulated in a microarray analysis of $j a w-D$, suggesting that they were targets of miR-JAW (Table 1; Palatnik et al., 2003). Sequence alignment of these TCP genes uncovered a conserved nucleotide sequence that was also present at the MIR-JAW locus. To confirm the negative regulation guided by miR-JAW, Palatnik et al. (2003) mapped the cleavage sites using modified 5' RACE and created cleavage-resistant versions of TCP2 and TCP4 by introducing silent mutations in the miR-JAW binding site. The effects of expressing these modified TCP2 or TCP4 genes in transgenic plants were more dramatic for TCP4 than for TCP2, the former determining organ fusions and the absence of the shoot apical meristem (Palatnik et al., 2003). All these results indicate that, by restricting the expression of TCP genes, miR-JAW regulates not only the development of leaves but also many other aspects of plant development (Palatnik et al., 2003).

\section{$\operatorname{miR} 159$}

Despite its sequence similarity to miR-JAW, miR159 seems to regulate a non-overlapping set of targets that includes the AtGAMYB genes MYB33 and MYB65 (Table 1; Palatnik et al., 2003). Both MYB33 and MYB65 contain sequences that allow miRNA regulation by miR159 (Palatnik et al., 2003). These genes code for MYB transcription factors related to barley GAMYB, a gibberellin-responsive transcriptional regulator that activates other gibberellinregulated genes (Gubler et al., 1999). The levels of miR159 also depend on gibberellic acid (GA), as inferred from their decrease in GA-deficient ga1 mutants or their increase after the application of exogenous GA (Achard et al., 2004).

Transgenic plants overexpressing miR159 showed several recognizable phenotypes. First, the transition to flowering was delayed under short day conditions, a phenotype attributable to decreased transcript levels of the AtGAMYB gene MYB33 and its putative target, the floral meristem identity gene $\angle E A F Y$ (Achard et al., 2004). Second, these plants were not fertile due to defective anther development (Achard et al., 2004), a phenotype also observed in myb33 myb65 double mutants (Millar and Gubler, 2005). The anther phenotype was conditionally restored under high-light or low-temperature conditions, indicating that the functionally redundant MYB33 and MYB65 genes are not fully essential for anther development (Millar and Gubler, 2005). Consistent with the phenotype, a translational MYB33:GUS fusion was expressed in the anthers (Millar and Gubler, 2005). A number of observations support the importance of miR159-mediated restriction of the spatial expression pattern of $M Y B 33$ in plant growth and development. The expression pattern expanded to tissues outside the anther in plants carrying a cleavage-resistant version of the MYB33:: GUS fusion, indicating the importance of miR159 for confining the expression to the anthers (Millar and Gubler, 2005). Palatnik et al. (2003) had previously reported that most plants expressing a miRNA-resistant version of MYB33 developed curled-up leaves, which indicates that the downregulation of $M Y B 33$ is important for normal leaf development. Besides leaf incurvature, the cleavage-resistant MYB33::GUS fusion conferred additional phenotypes, including rounded leaves with short petioles, a failure to expand the cotyledons, a small size, reduced apical dominance and low fertility (Millar and Gubler, 2005), suggesting that miR159 plays an important regulatory role in plant development.

\section{miR165 and miR166}

Multiple mutant combinations have shown that the five HD-ZIP III genes of Arabidopsis thaliana redundantly regulate important aspects of development, including the patterning of vasculature, the establishment or maintenance of abaxial-adaxial polarity in lateral organs and the function of meristems (Emery et al., 2003; Hawker and Bowman, 2004; Prigge et al., 2005). All the semidominant, gain-of-function alleles of four of them, PHB, PHV, REVOLUTA (REV) and INCURVATA4 (ICU4 ; Serrano-Cartagena et al., 2000), the latter also known as ATHB-15 and CORONA (CNA), damage a complementary site for miR165 and miR166 located in the START domain characteristic of HD-ZIP III proteins (Figure 2B) and confer pleiotropic phenotypes affecting the processes mentioned above (Figure 1H; McConnell and Barton, 1998; McConnell et al., 2001; Eshed et al., 2001; Emery et al., 2003; Juarez et al., 2004; McHale and Koning, 2004; Zhong and Ye, 2004; Green etal., 2005; Kim et al., 2005; Prigge et al., 2005; Ochando et al., submitted).

The miR165 and miR166 miRNAs are very similar in sequence and derive from multiple loci in the genome (Reinhart et al., 2002). 
Evidence supporting the miRNA-guided cleavage of $R E V, P H B$, PHV, ATHB-8 and ICU4 (ATHB-15 and CNA) comes from different sources. First, the cleaved products have been identified using modified 5' RACE (Emery et al., 2003; Mallory et al., 2004a; Kim et al., 2005). Second, HD-ZIP III genes are downregulated by an activation tagged allele of $\mathrm{miR} 166 \mathrm{a}$, men 1 , as is to be expected if they are targets of miR166 (Kim et al., 2005). Third, the introduction of cleavage-resistant versions of $R E V$ (rev- $\delta$ miRNA; Figure 2B) and of PHB (PHB G202G; PHB P201P; PHB K200K; Figure $2 B$ ) in wild-type plants phenocopied the effects of gainfunction rev and phb mutations (Emery etal., 2003; Mallory etal., 2004a). Fourth, we have found synergistic phenotypes in double mutants involving the gain-of-function icu4-1 mutation (which damages its miR165/166 binding site; Figures 1H, 2B) and lossof-function alleles of genes of the miRNA pathway, such as AGO1 or HYL1 (Jover-Gil et al., submitted; Figure 1M, N). Lastly, the study of dominant alleles of $P H B$ and $P H V$ has led to a model of transcriptional repression in cis guided by miRNAs (see 'Transcriptional regulation by miRNAs' above; Bao et al., 2004).

\section{miR164}

The cleavage of several NAC-domain genes is mediated by miR164, including CUC1, CUC2 and NAC1 (Table 1; Laufs et al., 2004; Mallory et al., 2004b; Baker et al., 2005). Reflecting this, plants overexpressing MIR164a and MIR164b showed cotyledon and floral organ fusions similar to those of CUC1 CUC2 double mutants (Aida et al., 1997; Laufs et al., 2004; Mallory et al., 2004b) and had reduced levels of CUC1 and CUC2 transcripts (Laufs et al., 2004). It has been proposed that the leaf and stem fusions observed in these plants, but not observed in cuc1 cuc2 double mutants, arise from the downregulation of other target genes, such as At5g07680, At5g61430 or NAC1 (Laufs et al., 2004; Mallory et al., 2004b).

The transcripts of CUC1, CUC2 and NAC1 are cleaved at the miR164 binding site in wild-type plants (Mallory et al., 2004b). The abnormal embryonic, vegetative and floral development and a boundary enlargement phenotype caused by miR164-resistant versions of CUC1 and CUC2 supports a role for miR164 in the control of boundary size in meristems and the formation and separation of embryonic, vegetative and floral organs (Laufs et al., 2004; Mallory et al., 2004b). The absence of a mutant phenotype in a null MIR164b mutant points to overlapping functions with other MIR164 genes, such as MIR164a (Mallory etal., 2004b). The early extra petals 1 (eep1) mutant led to the identification of a third locus for this miRNA, MIR164C (Table 1; Baker et al., 2005). Loss of function of $M I R 164 c$ causes an increase in the number of petals, demonstrating that at least some members of a miRNA family play specific functions that can be uncovered through mutational analysis (Baker et al., 2005).

\section{miR172}

Several members of the APETALA2 (AP2) family are predicted targets of miR172, including the floral homeotic gene AP2 and the TARGET OF EAT1 (TOE1), TOE2 and TOE3 genes in Arabidopsis thaliana and INDETERMINATE SPIKELET1 and GLOSSY15 in Zea mays (Table 1; Park et al., 2002; Aukerman and Sakai, 2003). So far, miR172 is the only known plant miRNA that acts through translational repression, as most animal miRNAs, rather than the cleavage of target transcripts (Aukerman and Sakai, 2003; Chen, 2004). An activation tagged allele of one of the five MIR172 loci present in the genome of Arabidopsis thaliana, named early activation tagged (eat-D), causes the overexpression of miR172a-2 and the translational repression of AP2 (Aukerman and Sakai, 2003). Accordingly, the phenotype of eat- $D$ plants resembled that of ap2 mutants and included early flowering, missing petals and the homeotic conversion of sepals into carpels. While a $35 S-E A T$ transgene conditioned the same phenotype as eat- $D$ mutants, another one with a deletion of the 21-nucleotide miRNA had no effect, demonstrating that the overexpression of the miRNA was responsible for the mutant phenotype (Aukerman and Sakai, 2003). In the same screen, Aukerman and Sakai also found an activation-tagged allele of the miR172 target gene TOE1. The overexpression of TOE 1 in the toe 1-1d mutant caused delayed flowering. On the contrary, loss-of-function alleles of TOE1 and TOE2 caused early flowering, which indicates that these genes behave as flowering repressors. These results are consistent with the MIR172 genes functioning to control the flowering time and the identity of floral organs (Aukerman and Sakai, 2003; Chen, 2004).

\section{Perspectives}

The discovery of RNAi and the identification of let-7 stimulated searches for miRNAs and siRNAs in animals and plants, as well as searches for the proteins involved in these silencing phenomena (Elbashir et al., 2001; Lagos-Quintana etal., 2001). Some estimates indicate that about $1 \%$ of the genes in animal genomes code for miRNAs (Lai et al., 2003; Lim et al., 2003a; $2003 \mathrm{~b}$ ) and that more than $20 \%$ of the human genes may be controlled by miRNAs (Lewis et al., 2005; Xie et al., 2005). In Arabidopsis thaliana, an increasing number of miRNAs have been found to be involved in the regulation of developmental processes, such as the transition to flowering, the function of meristems, the morphogenesis of leaves, the patterning of the vasculature or the development of flowers. The availability of genomic sequences for additional plant species (maize, poplar, rice, sorghum), as well as of improved protocols and computational algorithms for miRNA identification, will help to increase the pool of known miRNA genes in plant genomes. With the identification of new targets, we will also gain insight on the developmental pathways regulated by miRNAs.

Our knowledge of the miRNA biogenesis is growing quickly, as shown by recent reports on new components of the pathway and on their functions in plants and animals. Additional components will certainly be identified using biochemical and genetic techniques. Among these, mutational screens may take advantage of already-known components of the miRNA pathway by searching for enhancers or suppressors of the phenotypes associated to these components. A better understanding on miRNA biogenesis, regulation and function will open the door to the design of artificial miRNAs that may be used as efficient tools for controlling gene expression at will.

\section{Acknowledgements}

The authors wish to thank C. Llave and V. Quesada for comments on the manuscript and P. Robles and J.M. Barrero for kindly providing some 
of the illustrations. This research was supported by grant BMC200309763 to M.R.P. and a fellowship to S.J.-G. from the Ministerio de Educación y Ciencia of Spain.

\section{References}

ABRAHANTE, J.E., DAUL, A.L., LI, M., VOLK, M.L., TENNESSEN, J.M., MILLER, E.A. and ROUGVIE, A.E. (2003). The Caenorhabditis elegans hunchback-like gene lin-57/hb/-1 controls developmental time and is regulated by microRNAs. Dev. Cell 4: 625-637.

ACHARD, P., HERR, A., BAULCOMBE, D.C. and HARBERD, N.P. (2004). Modulation of floral development by a gibberellin-regulated microRNA. Development 131: 3357-3365.

ADAI, A., JOHNSON, C., MLOTSHWA, S., ARCHER-EVANS, S., MANOCHA, V., VANCE, V. and SUNDARESAN, V. (2005). Computational prediction of miRNAs in Arabidopsis thaliana. Genome Res. 15: 78-91.

AIDA, M., ISHIDA, T., FUKAKI, H., FUJISAWA, H. and TASAKA, M. (1997). Genes involved in organ separation in Arabidopsis : an analysis of the cup-shaped cotyledon mutant. Plant Cell 9: 841-857.

ALLEN, E., XIE, Z., GUSTAFSON, A.M., SUNG, G.H., SPATAFORA, J.W. and CARRINGTON, J.C. (2004). Evolution of microRNA genes by inverted duplication of target gene sequences in Arabidopsis thaliana. Nat. Genet. 36: 12821290.

AMBROS, V. (1989). A hierarchy of regulatory genes controls a larva-to-adult developmental switch in C. elegans. Cell 57: 49-57.

AMBROS, V., BARTEL, B., BARTEL, D.P., BURGE, C.B., CARRINGTON, J.C., CHEN, X., DREYFUSS, G., EDDY, S.R., GRIFFITHS-JONES, S., MARSHALL, M., MATZKE, M., RUVKUN, G. and TUSCHL, T. (2003a). A uniform system for microRNA annotation. RNA 9: 277-279.

AMBROS, V., LEE, R.C., LAVANWAY, A., WILLIAMS, P.T. and JEWELL, D. (2003b). MicroRNAs and other tiny endogenous RNAs in C. elegans. Curr. Biol. 13: $807-818$.

AMBROS, V. (2004). The functions of animal microRNAs. Nature 431: 350-355.

ARASU, P., WIGHTMAN, B. and RUVKUN, G. (1991). Temporal regulation of lin14 by the antagonistic action of two other heterochronic genes, lin- 4 and lin28. Genes Dev. 5: 1825-1833.

ARAVIN, A.A., LAGOS-QUINTANA, M., YALCIN, A., ZAVOLAN, M., MARKS, D., SNYDER, B., GAASTERLAND, T., MEYER, J. and TUSCHL, T. (2003). The small RNA profile during Drosophila melanogaster development. Dev. Cell 5: 337-350.

AUKERMAN, M.J. and SAKAI, H. (2003). Regulation of flowering time and floral organ identity by a microRNA and its APETALA2-Like target genes. Plant Cell 15: $2730-2741$

BAKER, C.C., SIEBER, P., WELLMER, F. and MEYEROWITZ, E.M. (2005). The early extra petals 1 mutant uncovers a role for microRNA miR164c in regulating petal number in Arabidopsis. Curr. Biol. 15: 303-315.

BAO, N., LYE, K.W. and BARTON, M.K. (2004). MicroRNA binding sites in Arabidopsis class III HD-ZIP mRNAs are required for methylation of the template chromosome. Dev. Cell 7: 653-662.

BARTEL, B. and BARTEL, D.P. (2003). MicroRNAs: at the root of plant development? Plant Physiol. 132: 709-717.

BARTEL, D.P. (2004). MicroRNAs: genomics, biogenesis, mechanism and function. Cell 116: 281-297.

BERNSTEIN, E., CAUDY, A.A., HAMMOND, S.M. and HANNON, G.J. (2001). Role for a bidentate ribonuclease in the initiation step of RNA interference. Nature 409: 363-366.

BILLY, E., BRONDANI, V., ZHANG, H., MULLER, U. and FILIPOWICZ, W. (2001). Specific interference with gene expression induced by long, double-stranded RNA in mouse embryonal teratocarcinoma cell lines. Proc. Natt. Acad. Sci. USA 98: 14428-14433.

BOHMERT, K., CAMUS, I., BELLINI, C., BOUCHEZ, D., CABOCHE, M. and BENNING, C. (1998). AGO1 defines a novel locus of Arabidopsis controlling leaf development. EMBO J. 17: 170-180.

BOHNSACK, M.T., CZAPLINSKI, K. and GORLICH, D. (2004). Exportin 5 is a RanGTP-dependent dsRNA-binding protein that mediates nuclear export of
pre-miRNAs. RNA 10: 185-191.

BOLLMAN, K.M., AUKERMAN, M.J., PARK, M.Y., HUNTER, C., BERARDINI, T.Z. and POETHIG, R.S. (2003). HASTY, the Arabidopsis ortholog of exportin 5/ MSN5, regulates phase change and morphogenesis. Development 130: 14931504.

BONNET, E., WUYTS, J., ROUZE, P. and VAN DE PEER, Y. (2004). Detection of 91 potential conserved plant microRNAs in Arabidopsis thaliana and Oryza sativa identifies important target genes. Proc. Natl. Acad. Sci. USA 101:1151111516.

BOUTET, S., VAZQUEZ, F., LIU, J., BECLIN, C., FAGARD, M., GRATIAS, A., MOREL, J.B., CRETE, P., CHEN, X. and VAUCHERET, H. (2003). Arabidopsis HEN1: a genetic link between endogenous miRNA controlling development and siRNA controlling transgene silencing and virus resistance. Curr. Biol. 13: 843848.

BRENNECKE, J., HIPFNERM, D.R., STARK, A., RUSSELL, R.B. and COHEN, S.M. (2003). bantam encodes a developmentally regulated microRNA that controls cell proliferation and regulates the proapoptotic gene hid in Drosophila. Cell 113: 25-36.

BRENNER, S. (1974). The genetics of Caenorhabditis elegans. Genetics 77: 7194.

CAI, X., HAGEDORN, C.H. and CULLEN, B.R. (2004). Human microRNAs are processed from capped, polyadenylated transcripts that can also function as mRNAs. RNA 10: 1957-1966.

CARMELL, M.A., XUAN, Z., ZHANG, M.Q. and HANNON, G.J. (2002). The Argonaute family: tentacles that reach into RNAi, developmental control, stem cell maintenance and tumorigenesis. Genes Dev. 16: 2733-2742.

CASTLE, L.A., ERRAMPALLI, D., ATHERTON, T.L., FRANZMANN, L.H., YOON, E.S. and MEINKE, D.W. (1993). Genetic and molecular characterization of embryonic mutants identified following seed transformation in Arabidopsis. Mol. Gen. Genet. 241: 504-514.

CERUTTI, L., MIAN, N. and BATEMAN, A. (2000). Domains in gene silencing and cell differentiation proteins: the novel PAZ domain and redefinition of the Piwi domain. Trends Biochem. Sci. 25: 481-482.

CHANG, S., JOHNSTON, R.J. Jr., FROKJAER-JENSEN, C., LOCKERY, S. and HOBERT, O. (2004). MicroRNAs act sequentially and asymmetrically to control chemosensory laterality in the nematode. Nature 430: 785-789.

CHEN, X. (2004). A microRNA as a translational repressor of APETALA2 in Arabidopsis flower development. Science 303: 2022-2025.

CHEN, X., LIU, J., CHENG, Y. and JIA, D. (2002). HEN1 functions pleiotropically in Arabidopsis development and acts in $\mathrm{C}$ function in the flower. Development 129: 1085-1094

CHEN, C.Z., LI, L., LODISH, H.F. and BARTEL, D.P. (2004). MicroRNAs modulate hematopoietic lineage differentiation. Science 303: 83-86.

CUBAS, P., LAUTER, N., DOEBLEY, J. and COEN, E. (1999). The TCP domain: a motif found in proteins regulating plant growth and development. Plant J. 18: 215-222.

DENLI, A.M., TOPS, B.B., PLASTERK, R.H., KETTING, R.F. and HANNON, G.J. (2004). Processing of primary microRNAs by the Microprocessor complex. Nature 432: 231-235.

DUGAS, D.V. and BARTEL, B. (2004). MicroRNA regulation of gene expression in plants. Curr. Opin. Plant Biol. 7: 512-520.

EDDY, S.R. (1999). Noncoding RNA genes. Curr. Opin. Genet. Dev. 9: 695-699.

ELBASHIR, S.M., LENDECKEL, W. and TUSCHL, T. (2001). RNA interference is mediated by 21- and 22-nucleotide RNAs. Genes Dev. 15: 188-200.

EMERY, J.F., FLOYD, S.K., ALVAREZ, J., ESHED, Y., HAWKER, N.P., IZHAKI, A., BAUM, S.F. and BOWMAN, J.L. (2003). Radial patterning of Arabidopsis shoots by class III HD-ZIP and KANADI genes. Curr. Biol. 13: 1768-1774.

ERRAMPALLI, D., PATTON, D., CASTLE, L., MICKELSON, L., HANSEN, K., SCHNALL, J., FELDMANN, K. and MEINKE, D. (1991). Embryonic lethals and T-DNA insertional mutagenesis in Arabidopsis. Plant Cell 3: 149-157.

ESHED, Y., BAUM, S.F., PEREA, J.V. and BOWMAN, J.L. (2001). Establishment of polarity in lateral organs of plants. Curr. Biol. 11: 1251-1260.

FAGARD, M., BOUTET, S., MOREL, J.B., BELLINI, C. and VAUCHERET, H. (2000). AGO1, QDE-2 and RDE-1 are related proteins required for posttranscriptional gene silencing in plants, quelling in fungi and RNA interference 
in animals. Proc. Natl. Acad. Sci. USA 97: 11650-11654.

FIRE, A., XU, S., MONTGOMERY, M.K., KOSTAS, S.A., DRIVER, S.E. and MELLO, C.C. (1998). Potent and specific genetic interference by doublestranded RNA in Caenorhabditis elegans. Nature 391: 806-811.

FLOYD, S.K. and BOWMAN, J.L. (2004). Gene regulation: ancient microRNA target sequences in plants. Nature 428: 485-486.

FRANZMANN, L.H., YOON, E.S. and MEINKE, D.W. (1995). Saturating the genetic map of Arabidopsis thaliana with embryonic mutations. Plant J. 7: 341-350.

GREEN, K.A., PRIGGE, M.J., KATZMAN, R.B. and CLARK, S.E. (2005). CORONA, a Member of the Class III Homeodomain Leucine Zipper Gene Family in Arabidopsis, Regulates Stem Cell Specification and Organogenesis. Plant Cell 17: 691-704.

GREGORY, R.I., YAN, K.P., AMUTHAN, G., CHENDRIMADA, T., DORATOTAJ, B., $\mathrm{COOCH}$, N. and SHIEKHATTAR, R. (2004). The Microprocessor complex mediates the genesis of microRNAs. Nature 432: 235-240.

GRIFFITHS-JONES, S. (2004). The microRNA Registry. Nucleic Acids Res. 32: D109-D111.

GRIFFITHS-JONES, S., MOXON, S., MARSHALL, M., KHANNA, A., EDDY, S.R. and BATEMAN, A. (2005). Rfam: annotating non-coding RNAs in complete genomes. Nucleic Acids Res. 33: D121-D124.

GRISHOK, A., PASQUINELLI, A.E., CONTE, D., LI, N., PARRISH, S., HA, I., BAILLIE, D.L., FIRE, A., RUVKUN, G. and MELLO, C.C. (2001). Genes and mechanisms related to RNA interference regulate expression of the small temporal RNAs that control C. elegans developmental timing. Cel/ 106: 23-34.

GROBHANS, H., JOHNSON, T., REINERT, K.L., GERSTEIN, M. and SLACK, F.J. (2005). The temporal patterning microRNA let-7 regulates several transcription factors at the larval to adult transition in C. elegans. Dev. Cell 8: 321-330.

GUBLER, F., RAVENTOS, D., KEYS, M., WATTS, R., MUNDY, J. and JACOBSEN, J.V. (1999). Target genes and regulatory domains of the GAMYB transcriptional activator in cereal aleurone. Plant J. 17: 1-9.

GUSTAFSON, A.M., ALLEN, E., GIVAN, S., SMITH, D., CARRINGTON, J.C. and KASSCHAU, K.D. (2005). ASRP: the Arabidopsis Small RNA Project Database. Nucleic Acids Res. 33 Database Issue: D637-D640.

HAMMOND, S.M., BERNSTEIN, E., BEACH, D. and HANNON, G.J. (2000). An RNA-directed nuclease mediates post-transcriptional gene silencing in Drosophila cells. Nature 404: 293-296.

HAMMOND, S.M., CAUDY, A.A. and HANNON, G.J. (2001). Post-transcriptional gene silencing by double-stranded RNA. Nat. Rev. Genet. 2: 110-119.

HAN, J., LEE, Y., YEOM, K.H., KIM, Y.K., JIN, H. and KIM, V.N. (2004a). The Drosha-DGCR8 complex in primary microRNA processing. Genes Dev. 18: 3016-3027.

HAN, M.H., GOUD, S., SONG, L. and FEDOROFF, N. (2004b). The Arabidopsis double-stranded RNA-binding protein HYL1 plays a role in microRNA-mediated gene regulation. Proc. Natl. Acad. Sci. USA 101: 1093-1098.

HAWKER, N.P. and BOWMAN, J.L. (2004). Roles for Class III HD-Zip and KANADI genes in Arabidopsis root development. Plant Physiol. 135: 2261-2270.

$\mathrm{HE}$, L. and HANNON, G.J. (2004). MicroRNAs: small RNAs with a big role in gene regulation. Nat. Rev. Genet. 5: 522-531.

HORVITZ, R.H. and SULSTON, J.E. (1980). Isolation and genetic characterization of cell-lineage mutants of the nematode Caenorhabditis elegans. Genetics 96: 435-454.

HUNTER, C. and POETHIG, R.S. (2003). miSSING LINKS: miRNAs and plant development. Curr. Opin. Genet. Dev. 13: 372-378.

JACOBSEN, S.E., RUNNING, M.P. and MEYEROWITZ, E.M. (1999). Disruption of an RNA helicase/RNAse III gene in Arabidopsis causes unregulated cell division in floral meristems. Development 126: 5231-5243.

JOHNSTON, R.J. and HOBERT, O. (2003). A microRNA controlling left/right neuronal asymmetry in Caenorhabditis elegans. Nature 426: 845-849.

JONES-RHOADES, M.W. and BARTEL, D.P. (2004). Computational Identification of Plant MicroRNAs and Their Targets, Including a Stress-Induced miRNA. Mol. Cell 14: 787-799.

JUAREZ, M.T., KUI, J.S., THOMAS, J., HELLER, B.A. and TIMMERMANS, M.C. (2004). miRNA-mediated repression of rolled/eaf1 specifies maize leaf polarity. Nature 428: 84-88.

KASSCHAU, K.D., XIE, Z., ALLEN, E., LLAVE, C., CHAPMAN, E.J., KRIZAN, K.A. and CARRINGTON, J.C. (2003). P1/HC-Pro, a viral suppressor of RNA silencing, interferes with Arabidopsis development and miRNA function. Dev. Cel/ 4 205-217.

KETTING, R.F., FISCHER, S.E., BERNSTEIN, E., SIJEN, T., HANNON, G.J. and PLASTERK, R.H. (2001). Dicer functions in RNA interference and in synthesis of small RNA involved in developmental timing in C. elegans. Genes Dev. 15: 2654-2659.

KIDNER, C.A. and MARTIENSSEN, R.A. (2004). Spatially restricted microRNA directs leaf polarity through ARGONAUTE1. Nature 428: 81-84.

KIM, J., JUNG, J.-H., REYES, J.L., KIM, Y.-S., KIM, S.-Y., CHUNG, K.-S., KIM, J.A., LEE, M., LEE, Y., KIM, V.N., CHUA, N.-H. and PARK, C.-M. (2005). microRNAdirected cleavage of $A T H B 15$ mRNA regulates vascular development in Arabidopsis inflorescence stems. Plant J. 42: 84-94.

KURIHARA, Y. and WATANABE, Y. (2004). Arabidopsis micro-RNA biogenesis through Dicer-like 1 protein functions. Proc. Natl. Acad. Sci. USA 101: 1275312758

LAGOS-QUINTANA, M., RAUHUT, R., LENDECKEL, W. and TUSCHL, T. (2001). Identification of novel genes coding for small expressed RNAs. Science 294 853-858.

LAI, E.C., TOMANCAK, P., WILLIAMS, R.W. and RUBIN, G.M. (2003). Computational identification of Drosophila microRNA genes. Genome Biol. 4: R42.1 R42.20.

LANDTHALER, M., YALCIN, A. and TUSCHL, T. (2004). The human DiGeorge syndrome critical region gene 8 and its $D$. melanogaster homolog are required for miRNA biogenesis. Curr. Biol. 14: 2162-2167.

LANG, J.D., RAY, S. and RAY, A. (1994). sin1, a mutation affecting female fertility in Arabidopsis, interacts with mod1, its recessive modifier. Genetics 137:11011110.

LAU, N.C., LIM, L.P., WEINSTEIN, E.G. and BARTEL, D.P. (2001). An abundant class of tiny RNAs with probable regulatory roles in Caenorhabditis elegans.Science 294: 858-862.

LAUFS, P., PEAUCELle, A., MORIN, H. and TRAAS, J. (2004). MicroRNA regulation of the $C U C$ genes is required for boundary size control in Arabidopsis meristems. Development 131: 4311-4322.

LEE, R.C., FEINBAUM, R.L. and AMBROS, V. (1993). The C. elegans heterochronic gene lin-4 encodes small RNAs with antisense complementarity to lin-14. Cell 75: 843-854

LEE, R.C. and AMBROS, V. (2001). An extensive class of small RNAs in Caenorhabditis elegans. Science 294: 862-864.

LEE, Y., JEON, K., LEE, J.T., KIM, S. and KIM, V.N. (2002). MicroRNA maturation: stepwise processing and subcellular localization. EMBO J. 21: 4663-4670.

LEE, Y., AHN, C., HAN, J., CHOI, H., KIM, J., YIM, J., LEE, J., PROVOST, P., RADMARK, O., KIM, S. and KIM, V.N. (2003). The nuclear RNase III Drosha initiates microRNA processing. Nature 425: 415-419.

LEE, Y., KIM, M., HAN, J., YEOM, K.H., LEE, S., BAEK, S.H. and KIM, V.N. (2004) MicroRNA genes are transcribed by RNA polymerase II. EMBO J. 23: 4051. 4060.

LEWIS, B.P., BURGE, C.B. and BARTEL, D.P. (2005). Conserved seed pairing, often flanked by adenosines, indicates that thousands of human genes are microRNA targets. Cel/ 120: 15-20.

LIM, L.P., LAU, N.C., WEINSTEIN, E.G., ABDELHAKIM, A., YEKTA, S., RHOADES M.W., BURGE, C.B. and BARTEL, D.P. (2003a). The microRNAs of Caenorhabditis elegans. Genes Dev. 17: 991-1008.

LIM, L.P., GLASNER, M.E., YEKTA, S., BURGE, C.B. and BARTEL, D.P. (2003b) Vertebrate microRNA genes. Science 299: 1540.

LIN, S.Y., JOHNSON, S.M., ABRAHAM, M., VELLA, M.C., PASQUINELLI, A., GAMBERI, C., GOTTLIEB, E. and SLACK, F.J. (2003). The C. elegans hunchback homolog, $h b l-1$, controls temporal patterning and is a probable microRNA target. Dev. Cell 4: 639-650.

LINGEL, A., SIMON, B., IZAURRALDE, E. and SATTLER, M. (2003). Structure and nucleic-acid binding of the Drosophila Argonaute 2 PAZ domain. Nature 426: 465-469.

LIU, J., CARMELL, M.A., RIVAS, F.V., MARSDEN, C.G., THOMSON, J.M., SONG, J.J., HAMMOND, S.M., JOSHUA-TOR, L. and HANNON, G.J. (2004). Argonaute2 is the catalytic engine of mammalian RNAi. Science 305: 1437-1441.

LLAVE, C., XIE, Z., KASSCHAU, K.D. and CARRINGTON, J.C. (2002a). Cleavage 
of Scarecrow-like mRNA targets directed by a class of Arabidopsis miRNA. Science 297: 2053-2056.

LLAVE, C., KASSCHAU, K.D., RECTOR, M.A. and CARRINGTON, J.C. (2002b) Endogenous and silencing-associated small RNAs in plants. Plant Cell 14: 1605-1619.

LU, C. and FEDOROFF, N. (2000). A mutation in the Arabidopsis HYL1 gene encoding a dsRNA binding protein affects responses to abscisic acid, auxin and cytokinin. Plant Cell 12: 2351-2366.

LUND, E., GUTTINGER, S., CALADO, A., DAHLBERG, J.E. and KUTAY, U. (2004). Nuclear export of microRNA precursors. Science 303: 95-98.

MALLORY, A.C., REINHART, B.J., JONES-RHOADES, M.W., TANG, G., ZAMORE, P.D., BARTON, M.K. and BARTEL, D.P. (2004a). MicroRNA control of PHABULOSA in leaf development: importance of pairing to the microRNA 5 region. EMBO J. 23: 3356-3364.

MALLORY, A.C., DUGAS, D.V., BARTEL, D.P. and BARTEL, B. (2004b). MicroRNA regulation of NAC-domain targets is required for proper formation and separation of adjacent embryonic, vegetative and floral organs. Curr. Biol. 14: 10351046.

MARTINEZ, J. and TUSCHL, T. (2004). RISC is a 5' phosphomonoester-producing RNA endonuclease. Genes Dev. 18: 975-980.

MCCONNELL, J.R. and BARTON, M.K. (1998). Leaf polarity and meristem formation in Arabidopsis. Development 125: 2935-2942.

MCCONNELL, J.R., EMERY, J., ESHED, Y., BAO, N., BOWMAN, J. and BARTON, M.K. (2001). Role of PHABULOSA and PHAVOLUTA in determining radial patterning in shoots. Nature 411: 709-713.

MCELVER, J., TZAFRIR, I., AUX, G., ROGERS, R., ASHBY, C., SMITH, K., THOMAS, C., SCHETTER, A., ZHOU, Q., CUSHMAN, M.A., TOSSBERG, J., NICKLE, T., LEVIN, J.Z., LAW, M., MEINKE, D. and PATTON, D. (2001). Insertional mutagenesis of genes required for seed development in Arabidopsis thaliana. Genetics 159: 1751-1763.

MCHALE, N.A. and KONING, R.E. (2004). microRNA-directed cleavage of Nicotiana sy/vestris PHAVOLUTA mRNA regulates the vascular cambium and structure of apical meristems. Plant Cell 16: 1730-1740

MEISTER, G., LANDTHALER, M., PATKANIOWSKA, A., DORSETT, Y., TENG, G. and TUSCHL, T. (2004). Human Argonaute2 mediates RNA cleavage targeted by miRNAs and siRNAs. Mol. Cell. 15: 185-197.

MILLAR, A.A. and GUBLER, F. (2005). The Arabidopsis GAMYB-Like Genes, MYB33 and MYB65, Are MicroRNA-Regulated Genes That Redundantly Facilitate Anther Development. Plant Cell 17: 705-721.

MONTGOMERY, M.K., XU, S. and FIRE, A. (1998). RNA as a target of doublestranded RNA-mediated genetic interference in Caenorhabditis elegans. Proc. Natl. Acad. Sci. USA 95: 15502-15507.

MOREL, J.B., GODON, C., MOURRAIN, P., BECLIN, C., BOUTET, S., FEUERBACH, F., PROUX, F. and VAUCHERET, H. (2002). Fertile hypomorphic ARGONAUTE (ago1) mutants impaired in post-transcriptional gene silencing and virus resistance. Plant Cell 14: 629-639.

MOSS, E.G., LEE, R.C. and AMBROS, V. (1997). The cold shock domain protein LIN-28 controls developmental timing in C. elegans and is regulated by the lin4 RNA. Cell 88: 637-646.

NAPOLI, C., LEMIEUX, C. and JORGENSEN, R. (1990). Introduction of a chimeric Chalcone Synthase gene into petunia results in reversible co-suppression of homologous genes in trans. Plant Cell 2: 279-289.

NATH, U., CRAWFORD, B.C., CARPENTER, R. and COEN, E. (2003). Genetic control of surface curvature. Science 299: 1404-1407.

NOMA, K., SUGIYAMA, T., CAM, H., VERDEL, A., ZOFALL, M., JIA, S., MOAZED, D. and GREWAL, S.I. (2004). RITS acts in cis to promote RNA interferencemediated transcriptional and post-transcriptional silencing. Nat. Genet. 36: 1174-1180.

OLSEN, P.H. and AMBROS, V. (1999). The lin-4 regulatory RNA controls developmental timing in Caenorhabditis elegans by blocking LIN-14 protein synthesis after the initiation of translation. Dev. Biol. 216: 671-680.

ORBAN, T.I. and IZAURRALDE, E. (2005). Decay of mRNAs targeted by RISC requires XRN1, the Ski complex and the exosome. RNA 11: 459-469.

PALATNIK, J.F., ALLEN, E., WU, X., SCHOMMER, C., SCHWAB, R., CARRINGTON, J.C. and WEIGEL, D. (2003). Control of leaf morphogenesis by miRNAs. Nature 425: 257-263.
PAPP, I., METTE, M.F., AUFSATZ, W., DAXINGER, L., SCHAUER, S.E., RAY, A., VAN DER WINDEN, J., MATZKE, M. and MATZKE, A.J. (2003). Evidence for nuclear processing of plant microRNA and short interfering RNA precursors. Plant Physiol. 132: 1382-1390.

PARIZOTTO, E.A., DUNOYER, P., RAHM, N., HIMBER, C. and VOINNET, O. (2004). In vivo investigation of the transcription, processing, endonucleolytic activity and functional relevance of the spatial distribution of a plant miRNA. Genes Dev. 18: 2237-2242.

PARK, W., LI, J., SONG, R., MESSING, J. and CHEN, X. (2002). CARPEL FACTORY, a Dicer homolog and HEN1, a novel protein, act in microRNA metabolism in Arabidopsis thaliana. Curr. Biol. 12: 1484-1495.

PARK, M.Y., WU, G., GONZALEZ-SULSER, A., VAUCHERET, H. and POETHIG, R.S. (2005). Nuclear processing and export of microRNAs in Arabidopsis. Proc Natl. Acad. Sci. USA 102: 3691-3696.

PARKER, J.S., ROE, S.M. and BARFORD, D. (2004). Crystal structure of a PIWI protein suggests mechanisms for siRNA recognition and slicer activity. EMBO J. 23: 4727-4737.

PASQUINELLI, A.E., REINHART, B.J., SLACK, F., MARTINDALE, M.Q., KURODA, M.I., MALLER, B., HAYWARD, D.C., BALL, E.E., DEGNAN, B., MULLER, P., SPRING, J., SRINIVASAN, A., FISHMAN, M., FINNERTY, J., CORBO, J., LEVINE, M., LEAHY, P., DAVIDSON, E. and RUVKUN, G. (2000). Conservation of the sequence and temporal expression of /et-7heterochronic regulatory RNA. Nature 408: 86-89.

POY, M.N., ELIASSON, L., KRUTZFELDT, J., KUWAJIMA, S., MA, X., MACDONALD, P.E., PFEFFER, S., TUSCHL, T., RAJEWSKY, N., RORSMAN, P. and STOFFEL, M. (2004). A pancreatic islet-specific microRNA regulates insulin secretion. Nature 432: 226-230.

PRIGGE, M.J., OTSUGA, D., ALONSO, J.M., ECKER, J.R., DREWS, G.N. and CLARK, S.E. (2005). Class III Homeodomain-Leucine Zipper Gene Family Members Have Overlapping, Antagonistic and Distinct Roles in Arabidopsis Development. Plant Cell 17: 61-76.

PROVOST, P., DISHART, D., DOUCET, J., FRENDEWEY, D., SAMUELSSON, B. and RADMARK, O. (2002). Ribonuclease activity and RNA binding of recombinant human Dicer. EMBO J. 21: 5864-5874.

RAND, T.A., GINALSKI, K., GRISHIN, N.V. and WANG, X. (2004). Biochemical identification of Argonaute2 as the sole protein required for RNA-induced silencing complex activity. Proc. Natl. Acad. Sci. USA 101: 14385-14389.

RAY, S., GOLDEN, T. and RAY, A. (1996). Maternal effects of the short integument mutation on embryo development in Arabidopsis. Dev. Biol. 180: 365-369.

REINHART, B.J., SLACK, F.J., BASSON, M., PASQUINELLI, A.E., BETTINGER, J.C., ROUGVIE, A.E., HORVITZ, H.R. and RUVKUN, G. (2000). The 21nucleotide let-7RNA regulates developmental timing in Caenorhabditis elegans. Nature 403: 901-906.

REINHART, B.J., WEINSTEIN, E.G., RHOADES, M.W., BARTEL, B. and BARTEL, D.P. (2002). miRNAs in plants. Genes Dev. 16: 1616-1626.

RHOADES, M.W., REINHART, B.J., LIM, L.P., BURGE, C.B., BARTEL, B. and BARTEL, D.P. (2002). Prediction of plant microRNA targets. Cel/ 110: 513-520.

ROBINSON-BEERS, K., PRUITT, R.E. and GASSER, C.S. (1992). Ovule development in wild-type Arabidopsis and two female sterile mutants. Plant Cell 4: 1237-1250.

SCHWARTZ, B.W., YEUNG, E.C. and MEINKE, D.W. (1994). Disruption of morphogenesis and transformation of the sus pensor in abnormal suspensor mutants of Arabidopsis. Development 120: 3235-3245.

SCHWARZ, D.S., TOMARI, Y. and ZAMORE, P.D. (2004). The RNA-induced silencing complex is a Mg2+-dependent endonuclease. Curr. Biol. 14: 787-791.

SEGGERSON, K., TANG, L. and MOSS, E.G. (2002). Two genetic circuits repress the Caenorhabditis elegans heterochronic gene lin-28 after translation initiation. Dev. Biol. 243: 215-225.

SERRANO-CARTAGENA, J., CANDELA, H., ROBLES, P., PONCE, M.R., PEREZPEREZ, J.M., PIQUERAS, P. and MICOL, J.L. (2000). Genetic analysis of incurvata mutants reveals three independent genetic operations at work in Arabidopsis leaf morphogenesis. Genetics 156: 1363-1377.

SHEN, B. and GOODMAN, H.M. (2004). Uridine addition after microRNA-directed cleavage. Science 306: 997.

SLACK, F.J., BASSON, M., LIU, Z., AMBROS, V., HORVITZ, H.R. and RUVKUN, G. (2000). The lin-41 RBCC gene acts in the $C$. elegans heterochronic pathway 


\section{S. Jover-Gil et al.}

between the let-7 regulatory RNA and the LIN-29 transcription factor. Mol. Cell 5: 659-669.

SONG, J.J., SMITH, S.K., HANNON, G.J. and JOSHUA-TOR, L. (2004). Crysta structure of Argonaute and its implications for RISC slicer activity. Science 305: 1434-1437.

SOURET, F.F., KASTENMAYER, J.P. and GREEN, P.J. (2004). AtXRN4 degrades mRNA in Arabidopsis and its substrates include selected miRNA targets. Mol. Cel/ 15: 173-183.

SUNKAR, R. and ZHU, J.K. (2004). Novel and stress-regulated microRNAs and other small RNAs from Arabidopsis. Plant Cell 16: 2001-2019.

TAHBAZ, N., KOLB, F.A., ZHANG, H., JARONCZYK, K., FILIPOWICZ, W. and HOBMAN, T.C. (2004). Characterization of the interactions between mammalian PAZ PIWI domain proteins and Dicer. EMBO Rep. 5: 189-194.

TANG, G., REINHART, B.J., BARTEL, D.P. and ZAMORE, P.D. (2003). A biochemical framework for RNA silencing in plants. Genes Dev. 17: 49-63.

TELFER, A. and POETHIG, R.S. (1998). HASTY: a gene that regulates the timing of shoot maturation in Arabidopsis thaliana. Development 125: 1889-1898.

TOMARI, Y. and ZAMORE, P. D. (2005) MicroRNA Biogenesis: Drosha Can't Cut It without a Partner. Curr. Biol. 15: R61-64.

VAN DER KROL, A.R., MUR, L.A., BELD, M., MOL, J.N. and STUITJE, A.R. (1990). Flavonoid genes in petunia: addition of a limited number of gene copies may lead to a suppression of gene expression. Plant Cell 2: 291-299.

VAUCHERET, H., VAZQUEZ, F., CRETE, P. and BARTEL, D.P. (2004). The action of ARGONAUTE1 in the miRNA pathway and its regulation by the miRNA pathway are crucial for plant development. Genes Dev. 18: 1187-1197.

VAZQUEZ, F., GASCIOLLI, V., CRETE, P. and VAUCHERET, H. (2004). The nuclear dsRNA binding protein $\mathrm{HYL1}$ is required for microRNA accumulation and plant development, but not posttranscriptional transgene silencing. Curr. Biol. 14: 346-351.

VERDEL, A., JIA, S., GERBER, S., SUGIYAMA, T., GYGI, S., GREWAL, S.I. and MOAZED, D. (2004). RNAi-mediated targeting of heterochromatin by the RITS complex. Science 303: 672-676.

WANG, J.F., ZHOU, H., CHEN, Y.Q., LUO, Q.J. and QU, L.H. (2004a). Identification of 20 microRNAs from Oryza sativa. Nucleic Acids Res. 32: 1688-1695.

WANG, X.J., REYES, J.L., CHUA, N.H. and GAASTERLAND, T. (2004b). Prediction and identification of Arabidopsis thaliana microRNAs and their mRNA targets. Genome Biol. 5: R65.1-R65.15.

WIGHTMAN, B., HA, I. and RUVKUN, G. (1993). Posttranscriptional regulation of the heterochronic gene lin-14 by lin-4 mediates temporal pattern formation in C. elegans. Cell 75: 855-862

XIE, Z., KASSCHAU, K.D. and CARRINGTON, J.C. (2003). Negative feedback regulation of Dicer-Like1 in Arabidopsis by miRNA-guided mRNA degradation. Curr. Biol. 13: 784-789.

XIE, X., LU, J., KULBOKAS, E.J., GOLUB, T.R., MOOTHA, V., LINDBLAD-TOH, K., LANDER, E.S. and KELLIS, M. (2005). Systematic discovery of regulatory motifs in human promoters and 3' UTRs by comparison of several mammals. Nature 434: 338-345

XU, P., VERNOOY, S.Y., GUO, M. and HAY, B.A. (2003). The Drosophila microRNA Mir-14 suppresses cell death and is required for normal fat metabolism. Curr. Biol 13: 790-795.

YAN, K.S., YAN, S., FAROOQ, A., HAN, A., ZENG, L. and ZHOU, M.M. (2003). Structure and conserved RNA binding of the PAZ domain. Nature 426: 468-474.

YI, R., QIN, Y., MACARA, I.G. and CULLEN, B.R. (2003). Exportin-5 mediates the nuclear export of pre-microRNAs and short hairpin RNAs. Genes Dev. 17:3011 3016.

YU, B., YANG, Z., LI, J., MINAKHINA, S., YANG, M., PADGETT, R.W., STEWARD, R. and CHEN, X. (2005). Methylation as a crucial step in plant microRNA biogenesis. Science 307: 932-935.

ZAMORE, P.D. (2002). Ancient pathways programmed by small RNAs. Science 296: 1265-1269

ZENG, Y., YI, R. and CULLEN, B.R. (2005). Recognition and cleavage of primary microRNA precursors by the nuclear processing enzyme Drosha. EMBO J. 24 138-148.

ZHONG, R. and YE, Z.H. (2004). amphivasal vascular bundle 1, a gain-of-function mutation of the IFL 1/REV gene, is associated with alterations in the polarity of leaves, stems and carpels. Plant Cell Physiol. 45: 369-385. 